\title{
Collections Mobility Today: How is the mobility of collections encour- aged in Slovakia and Czechia?
}

\author{
Marianna Tutková
}

Mgr. Marianna Tutková

Comenius University in Bratislava

Faculty of Arts

Department of Ethnology and Museology

Gondova 2

81499 Bratislava

Slovakia

e-mail: marianna.tutkova@uniba.sk

Muzeológia a kultúrne dedičstvo, 2021, 9:1:135-143

DOI: $10.46284 / \mathrm{mkd} .2021 .9 .1 .8$

\section{Collections Mobility Today: How is the mobility of collections encouraged in Slovakia and Czechia?}

The article is focused on the mobility of museum collections today in Slovakia and Czechia. The paper begins with a brief overview of the first specialist conferences to focus on the issue of collections mobility in Europe. It continues with an overview of present-day information support for sharing collections between museums in Slovakia and Czechia. It analyses the online activities of museums and cultural institutions and currently literature on the issue, as well as changes to legislation which affect the awareness of collections mobility and facilitate the process of loaning collection objects between museums. In particular, it summarises changes to the Slovak Law no. 207/2009 on conditions pertaining to the export and import of objects of cultural significance, which was amended in 2018. The conclusion includes a brief list of the most basic and, at the same time, the latest approaches to collections mobility in Europe.

Key words: collections mobility, collections in transfer, support for collections mobility, collection object, museum

\section{Introduction}

The safe deposit and protection of a collection object does not represent fulfilment of its role as a collection object. This state is only achieved after an expert scientific review has been conducted and the subsequent transfer of stored information to a person. Museums have radically changed their approach to their visitors' needs during the last two decades. They are more open $^{1}$ and they continue to seek more inventive forms of presentation. But what do museums need to do in order to take better advantage of the power of their collections and to make use of aspects of their collections that have been neglected until now? Overcrowded and unused collection objects located in depositories are not the only reason the mobility of collections is important. Placing collection objects directly in museum exhibitions helps to complete the essential context from which these objects can communicate stories from different points of view. ${ }^{2}$ In the twenty-first century, the mobility of collections has started to emerge as one of

\footnotetext{
${ }^{1}$ An interesting contribution on capitalizing on the received information and cultural values from expositions is available in the following article: BALLARINI, Marie, MOUGENOT, Chloé, PROKŮPEK, Marek. Evaluating the reception of an exhibition: DeTermination at the DOX Centre for Contemporary Art. In: Muzeologia a kulturne dedičstvo, year: 2019, vol.: 7, number: 1, pages: 41-55, ISSN 1339-2204.

${ }^{2}$ MENSCH, Peter van, MEIJER-VAN MENSCH, Leontine. New Trends in Museology II. Celje: Muzej novejšie zgodovine, 2015.
} 
the main tools providing visitors with wider access to collections. The journey towards greater collections mobility began with conferences on museology at the beginning of this century which tried to tackle the problems connected to the transfer of collection objects between museums in Europe. The role of museums and their collections in the twenty-first century and support for cultural heritage and its sharing were also themes in these conferences. One of the desired outcomes of these conferences was to develop a manual that summarized the theory of collections mobility and proposed an ideal plan-of-action for the transfer of collections between museums. The first attempts at improving the mobility of collections had also exposed difficulties that needed to be articulated and discussed, as a basis from which to find alternative methods and solutions. The progress made on the issue of collections mobility and the advancement of a shared vision for the current direction of museums was achieved as a result of these discussions, which took place within numerous conferences.

\section{First discussions on the issue of collections mobility}

The mobility of collections appeared as a main theme in the field of museology at a conference, held in 2003 in Athens and Delphi, under the name Enhancement and Promotion of Cultural Heritage of European Significance. Following this, many similarly themed conferences took place across Europe, and the resulting publications, in the form of proceedings, expert articles and reports, became fundamental documents for the support and realisation of the mobility of collections. One particularly significant publication for the mobility of collections was the 2005 report, Lending to Europe: Recommendations on collection mobility for European museums, ${ }^{3}$ presenting the conclusions of a working group of museum experts chaired by Ronald de Leeuw, Director General of the Rijksmuseum in Amsterdam. The document may be considered a founding stone of the theory of collections mobility. It presents a list of summarized ideas and information based on previous successful projects and offers practical advice on how to approach mobility.

The major turning point in the mobility of collections came with the rapid developments of 2006. Firstly, several conferences, including the Conference on Museum Training, Museum Collections and Planning (Madrid, Spain, Spanish Ministry of Culture) and Encouraging the Mobility of Collections (Helsinki, Finland, Ministry of Education and National Board of Antiquities) took place. Secondly, an important document on the mobility of collections, Action Plan for the EU Promotion of Museum Collections' Mobility and Loan Standards was published. ${ }^{4}$ The last, but nevertheless more important point is the creation of six working groups during the Austrian presidency to facilitate realisation the mobility of collections and find solutions for the problems this entails. The following thematic groups were created: standards (Austria); state indemnity, insurance, immunity from seizure, long-term loans and loan fees (Finland); and building up trust and networking (Germany). Europe has witnessed an expanding trend of conferences thematically oriented on collections mobility in Europe since 2006. Astrid Weij has composed a timeline of important milestones in the development of the mobility of collections based on specialist conferences, expert reports and other documentations, in her paper "Collections Mobility Ti-

\footnotetext{
${ }^{3}$ Lending to Europe. Rotterdam: Netherlands Ministry of Education, Culture and Science. Available at: https://www. muziejai.lt/ImagesNew/LENDINGTOEUROPE_PDF_051105.pdf. The document was created by a working group of museum experts during the Dutch presidency and was approved by EU Ministers of Culture on 23 of March 2015 during the presidency in Luxembourg. The goal was to facilitate the mobility of European collections. ${ }^{4}$ PETTERSSON, Susanna et al. (eds). Action Plan for the EU Promotion of Museum Collections Mobility and Loan Standards. Helsinki: Finnish National Gallery. Accessed October 10, 2019, at: https://uk.icom.museum/wp-content/ uploads/2015/03/Encouraging_Collections_Mobility_A4.pdf.
} 
meline", which was published in the collection Encouraging Collections Mobility: A Way Forward for Museums in Europe. ${ }^{5}$

The essence of these conferences is their effort to divert museums from hoarding and duplicating their collection fund and to lead them to being more open, to sharing, collaborations and mutual trust within the European museum network. Several conferences - their name a clue - were focused on various obstacles concerning increasing the movement of collections between museums. They came up with suggestions and proposed ways on how to eliminate the most pressing problems and make the process easier. These conferences and their documents are considered crucial. They began to form new ideas concerning museology and began to open many questions which changed the dogmas about museums.

The issue of collections mobility had been discussed between museums and in the cultural environment mainly on an international level. Most publications concerning expert solutions and assessments were published in English. In the next part of this article, we focus on the encouragement of collections mobility in Slovakia and in Czechia, considering the sharing of these documents in an online environment and possible translations into Slovak/Czech. We look closely at the changes to legislation pertaining to Slovak and Czech museology with the aim of creating a space from which to form a foundation for encouraging collections mobility in these countries, and for Slovak and Czech museums to participate in the affairs of European museums.

\section{Encouraging collections mobility in Czechia and in Slovakia}

The Methodological Centre for Visual Arts Museums in the National Gallery in Prague offers significant support for the mobility of collections by publishing expert documents, creating methodological manuals and helping institutions prepare in advance by introducing interactive forms for institutions to use. On their website, ${ }^{6}$ under "Mobility of Collections", all articles clarifying the issue of mobility are available to read, as a primary mission of the Cultural Affairs Committee. One useful article available there is "Art in Motion", by Dr Magda Nemcová, ${ }^{7}$ which summarizes the main factors influencing the mobility of collections in the Czech Republic. It also assesses the current situation of collection mobility in terms of legislative regulations. On October 9, 2019, the Methodological Centre prepared a workshop (the second in its series) entitled "The work of a specialist registrar in museums". 8 The aim of the workshop was to clarify the rules necessary for correct administration of a museum exposition, including the rules surrounding the international mobility of collections. A new method for mobilising collections, How to administrate a museum exhibition? (published in May 2019) was introduced in the workshop. The publication can be regarded as a manual summarizing basic procedures for the international mobility of collections from the perspective of both sides: the owner of the collection object and the recipient. It is based on some fundamental rules which were the

\footnotetext{
${ }^{5}$ WEIL, Astrid. Mobilita sbírek - Časový přehled. In: Podporujeme mobilitu sbirek: cesta upréd pro evropská muz̨ea [online]. Český preklad Praha: Metodické centrum pro muzea výtvarného umění v národní galerii v Praze, 2014. Accessed December 18, 2019 at: http://www.mcgalerie.cz/admin/files/pdf/ENCOURAGING-SBORNIK-konecna-verze. pdf. ISBN: 978-80-7035-555-8.

${ }^{6}$ Website of the Methodological Centre for Visual Arts Museums in the National Gallery in Prague: http://www. mc-galerie.cz.

${ }^{7}$ NEMCOVÁ, Magda. Art in Motion. Originally published in: Ateliér, 9, 2011.

${ }^{8}$ Information about the workshop is available at http://www.mc-galerie.cz/seminare-metodickehocentra/prace-registratora-specialisty-v-muzeich---workshop.html.
} 
result of work carried out under the European Cultural Agenda 2001-2010 involving the International Council of Museums, and cover issues such as contractual guarantees and common organisational procedures. The name of the workshop raised the question of who exactly a registrar specialist is. There is a section in How to administrate a museum exhibition? which bears the same name as the workshop, as well as annexes that include interactive forms. ${ }^{9}$ Without these forms, the international loan of collection objects would be extremely difficult. Museums and institutions are responsible for the collection object in the collection fund of their museum. That is why when a collection object is moved outside the museum where it normally resides and out of the country where the museum is located, the museums on both sides of the loan bear an enormous responsibility. The forms ensure that suitable conditions are established for the transfer of the object(s). The basic forms are: facility report, request for immunity from seizure, request for state guarantees - letter of comfort, a condition report and a checklist for the evaluation of collection objects.

Compared to Czech cultural institutions, the websites of Slovak cultural institutions do not strongly encourage collection mobility by promoting awareness of its possibilities. For this reason, I am going to highlight information from the Slovak legislation concerning the import and export of an object of cultural significance, and also some significant foreign publications translated into Slovak which are also available on Slovak websites.

In September 2012, the website of the Ministry of Culture of the Slovak Republic published the Toolkit, ${ }^{10}$ the final report of the OMC (Open Method of Coordination) Working Group, composed of museum experts from various European Union Member States which focused on collection mobility. This preparatory study, which took the form of a manual, was purposefully oriented on methods to reduce the cost of collection mobility. The Working Group primarily focused on proposing practical steps throughout, from recommendations to warnings about potentially problematic parts of the process. A more common name for the Toolkit is the "Set of tools concerning practical ways to reduce the cost of lending and borrowing of cultural objects among the Member States of the European union"11.

The Museological Committee of the Slovak National Museum (SNM) published a set of methodological instructions for its 18 specialised museums in 2014. The document, "Procedure for temporary export of collection items from the museums of the Slovak National Museum (SNM)", ${ }^{12}$ summarizes four essential components of the process of exporting a collection object: i) the export of collection objects within the customs territory of the EU; ii) modification of conditions of temporary export of collection objects; iii) the export of collection

\footnotetext{
${ }^{9}$ Forms can be viewed and downloaded from the Methodological Centre's website: http://www.mc-galerie.cz/ mobilita-sbirek-1/jak-administrovat-muzejni-vystavu--interaktivni-formulare.html.

${ }^{10}$ Súbor nástrojov týkajúci sa praktických spôsobov zniženia nákladov na požičiavanie a vypožiciavanie predmetov kultúrnej hodnoty medzi členskými státmi európskej únie [Toolkit on practical ways to reduce the cost of lending and borrowing of cultural objects among member states of the European Union.] Open Method of Coordination (OMC) Working Group of EU Member States' Experts on the Mobility of Collections. European Agenda for Culture, Work Plan for Culture 2011-2014. [In Slovak] Accessed October, 172019 at: http://kultur.creative-europe desk.de/fileadmin/ user_upload/omc_toolkit-mobility-ofcollections_en.pdf.

11 The Slovak mutation of the Toolkit method is available in translation on the website of the Ministry of Culture of the Slovak Republic. Accessed October, 152019 at: http://www.culture.gov.sk/extdoc/5846/3_ubor_nastrojov. 12 Procedure for temporary export of collection objects from the museums of the Slovak National Museum. Accessed October 19, 2019 at: http://www.snm.sk/swift_data/source/odborna_verejnost/dokumentacia/Postup_docas_vyvoz_ZP_SNM_130502014.doc.
} 
objects outside the territory of the EU; and iv) notification of the return of collection objects. This offered basic directions for all museums (not only the SNM) that wishing to organize a loan, reminding institutions that any request to export a collection object must be confirmed by the Director General of the Slovak National Museum and be submitted for approval to the establisher, i.e. the Ministry of Culture, and that for this reason, it is necessary to submit export requests well in advance. On the Slovakian Ministry of Culture's website, under the section "Cultural heritage", is a category "Export of objects of cultural significance". ${ }^{13}$ There are two parameters defining the export of an object of cultural significance: permanent/temporary and within/outside of the territory of the European Union. This categorization simplifies the orientation between regulations and directs the user to the relevant guidelines, with individual steps clarifying the procedures for exporting objects of cultural significance in accordance with the relevant legislation. Specific documents for each type of export are available to download, along with an attached description on how to fill out the document correctly. However, documents which are considered a standard tool for collection mobility in European museums, such as the aforementioned "Condition report", are not mentioned on the site. Nevertheless, the law on exporting and importing objects of cultural significance ${ }^{14}$ does require the creation of photo documentation and provision of an expert opinion on the value of the object before export. This documentation establishes the initial condition of the object before export, not its condition during the transfer or after it is received by the new host institution. The Ministry of Culture's website also provides no information about other documents which were created to support problem-free collection mobility. It explains the procedures linked to collection mobility only from the perspective of legal norms between the collections manager and the state. A new law entered into force in 2019, "Law No. 160/2018 of 15 May 2018, amending Law No. 207/2009 regulating the conditions of export and import of an object of cultural significance". ${ }^{15}$ The aim of the amendment was to improve the conditions governing the protection of objects of cultural significance and to secure suitable expert opinions. One aspect of the amendment was the creation of a new form for permission to export. This document introduced modifications based on international standards, including a requirement for the submission of an expert opinion to support the application. Taking the category of object of cultural significance into the account, the Ministry of Culture must request an opinion from one of the following institutions: the Monuments Board of the Slovak Republic, the Slovak National Gallery or the Slovak National Museum. The amendment to the original law is aimed at making requests for the export of objects of cultural significance more effective.

Immunity from seizure took some time to become part of Slovak legislation. The United Nations Convention on Jurisdictional Immunities of States and their Property ${ }^{16}$ was adopted in Resolution No. A/59/38 on the 59th session of the UN General Assembly on December

\footnotetext{
13 "Category Export of the object of cultural significance" can be found in the section Cultural Heritage section of the website of the Kultúry Slovenskej republiky website: http://www.culture.gov.sk/posobnostministerstva/ kulturne-dedicstvo-/vyvoz-predmetu-kulturnej-hodnoty--2ed.html.

${ }^{14}$ Zákon č. 160/2018 Z. z. o podmienkach vývozu a dovozu predmetu kultúrnej hodnoty a o doplnení zákona č. 52/2004 Z. z. o orgánoch štátnej správy v colníctve a o zmene a doplnení niektorých zákonov v znení neskorších predpisov v znení zákona č. 38/2014 Z. z. a ktorým sa menia a dopĺnajú niektoré zákony.

${ }^{15}$ Zmena zákona o vývoze a dovoze predmetu kultúrnej hodnoty. Zákon č. 160/2018 Z. z., Ref. 13. Available on-line on: https://www.noveaspi.sk/products/lawText/1/90299/1/2.

${ }^{16}$ United Nation Convention on the Jurisdictional Immunities of States and Their Property (New York, 2 December 2004); Document OSN A/RES/59/38. Available at: https://undocs.org/en/A/RES/59/38.
} 
2, 2004. Despite having signed the Convention ${ }^{17}$ in 2005, the Slovak Republic set a deadline of 31 December 2007 for a government hearing on incorporating it into Slovak legislation. The government hearing on the convention was cancelled a year later by Resolution No. 892 on 10 December 2008, due to technical reasons. The proposition to enact instruments of ratification of the United Nations Convention on Jurisdictional Immunities of States and their Property was adopted by the National Council of the Slovak Republic on June 3, 2015. ${ }^{18}$

State warranty offers significant encouragement for collection mobility. This was incorporated into the legislation of the Slovak Republic under Law No. 207/2009 "On conditions of export and import of objects of cultural significance". ${ }^{19}$ The law defines the rules for receiving this type of funding from the state budget in the event of damage that could arise during the transportation of a collection object from abroad to the territory of the Slovak Republic.

\section{Collections Mobility Today}

The mobility of collections appeared as a new subject in the field of museology at the beginning of the twenty-first century, especially in the context of museology conferences. The need for new ideas and approaches to collections that could potentially change classical and deep-rooted attitudes about preservation and collecting were the driving force in making collections mobility a common theme within museology discourse. New ideas for the strategic creation of collections have been put into motion in recent years, stepping away from outdated notions about improving museum collections by accumulating objects of cultural significance. European museums' collections are a rich source for learning about cultural heritage and they are the reason for mutual sharing. ${ }^{20}$

This fact is supported by current views on how to direct museums to their visitors. One of the attributes of rating is the visitors' assessment of the museums activities. It is the quality of museum products, the method of creation of presentations for example, and possible ways of interpreting information. ${ }^{21}$ Mobility of collections is a tool for improving the quality and availability of extraordinary collection objects in the museum representation. A collection object enables us to recognize different cultures, ethnicities or religions and even serves as a tool for bringing the cultures ${ }^{22}$ closer together.

These days, many experts advocate for greater efforts to facilitate the process of collection mobility. One of the steps towards facilitating the export and import of collections is immunity from seizure. This stipulation is not only designed for museums lending an object, but also for

\footnotetext{
${ }^{17}$ United Nation Convention on the Jurisdictional Immunities of States and Their Property. Available at: https:// www.nrsr.sk/web/Dynamic/DocumentPreview.aspx?DocID=417154

${ }^{18}$ Presentation report. Návrh na vyslovenie súhlasu Národnej rady Slovenskej republiky s Dohovorom Organizácie Spojených národov o jurisdikčných imunitách štátov a ich majetku sa predkladá v súlade s bodom C.1 uznesenia vlády Slovenskej republiky č. 297/2015 z 3. júna 2015. Available at: https://www.nrsr.sk/web/Dynamic/DocumentPreview.aspx?DocID $=417153$.

${ }^{19}$ Zákon č. 207/2009 z 28. apríla 2009 o podmienkach vývozu a dovozu predmetu kultúrnej hodnoty a o doplnení zákona č. 652/2004 Z. z. o orgánoch štátnej správy v colníctve a o zmene a doplnení niektorých zákonov v znení neskorších predpisov.

${ }^{20}$ Collections for the Future. Report of a Museums. London: Museums Association, 2005. Accessed November

3, 2019 at: https://www.museumsassociation.org/download?id=11121.

${ }^{21}$ ELIAŠOVÁ, Silvia. Motívy a metódy výskumu múzejného publika s dôrazom na podmienky slovenského múzejníctva. In: Muquológia a kulturne dedičstvo, year: 2019, vol.: 7, number: 1, pages: 27-39. ISSN: 1339-2204.

${ }^{22}$ See an article on the presentation of African art: PAWLOWSKA, Aneta. African Art: The Journey from Ethnological Collection to the Museum of Art. In: Muzeológia a kultúrne dedičstvo, year: 2020, vol.: 8, number: 4, pages: 161-176. ISSN 1339-2204.
} 
museums borrowing an object, protecting both museums from a third party that could claim rights over a collection item. For example, this would protect an object from being seized by the government of the receiving institution's country which claims historical property rights over the object. It also prevents collections mobility being used as a means to recover objects of disputed ownership held in foreign museums. ${ }^{23}$ Another possibility is the absence of commercial insurance. Law no. 160/180 on export and import of an object of cultural significance requires the custodian of a collection to submit an expert opinion on the value of the object before export, on the basis of which the level of commercial insurance can be set. This is an especially disputable subject, as commercial insurance is a well-known cause for increasing the cost of inter-museum loans of collection objects. Expert working groups ${ }^{24}$ have discussed ways to get around this problem, including not insuring or reducing the cost of insurance. One solution is long-term loans, which shortens the insurance period to cover the time taken to transport the object. Another solution is to replace commercial insurance with a state guarantee to repair any damage to the object in case of accident.

\section{Conclusion}

Cooperation between museums and the encouragement of collections mobility depends on building mutual relationships and trust. Specialist conferences on museology and the work of expert working groups in the field aiming to find ways to facilitate and boost collections mobility have shown that mutual cooperation and the suggestion of individual steps are key to successful cooperation between museums. Thanks to these efforts, a huge amount of experience and relevant information has been collated, leading to the publication of guidelines and recommendations aimed at encouraging collections mobility. Some of these publications have been translated into Slovak and present the right direction towards improving awareness about the significance of mutual cooperation between museums in this field. The paper specifies publications that were also translated into Czech, especially because of the language availability for Slovaks. The fact that the availability of information and support is much further ahead in the Czech Republic than in Slovakia is confirmed by the numerous publications this paper has mentioned.

In Slovakia, insufficient attention has been paid to collections mobility. With the exception of some translated publications, there is a low level of interest from experts, and no uniform manual for museums (except the aforementioned law) exists. The encouragement of collections mobility and exhibitions in Slovakia is worth mentioning and deserving of the interest of experts. The aim of collections mobility is to improve interactions between museums, create friendly museum networks and bring collection funds closer to the public. Collections mobility challenges us to find out whether we know the collection and how we may deepen that knowledge. The mobility of collections demands that we reassess common practices and encourages deeper research into the collections.

\footnotetext{
${ }^{23}$ WOUDENBERG, Nout van. Immunity from seizure: a legal exploration. In: Encouraging collections mobility - $A$ Way Forward for Museums in Europe. Accessed October 10, 2019 at: http:/ /www.lendingfor europe.eu/fileadmin/CM/ public/handbook/Encouraging_Collections_Mobility_A4.pdf

${ }^{24}$ Specific problems of collection mobility were discussed by the collection mobility group within the OMC Working Group between 2008 and 2010.
} 
M. Tutková: Collections Mobility Today: How is the mobility of collections encouraged in Slovakia and Czechia?

\section{References}

Action Plan for the EU Promotion of Museum Collection' Mobility and Loan Standards. Accessed October 10, 2019 at: https://uk.icom.museum/wp-content/uploads/2015/03/Encouraging_ Collections_Mobility_A4.pdf.

BALLARINI, Marie, MOUGENOT, Chloé, PROKŮPEK, Marek. Evaluating the reception of an exhibition: DeTermination at the DOX Centre for Contemporary Art. In: Muzeológia a kulturne dedičstvo, year: 2019, vol.: 7, number: 1, pages: 41-55, ISSN 1339-2204.

Collections for the Future. Report of a Museums. 2005. London: Museums Association 2005, London. Accessed November 3, 2019 at: https://www.museumsassociation.org/download?id=11121.

ELIAŠOVÁ, Silvia. 2019. Motívy a metódy výskumu múzejného publika s dôrazom na podmienky slovenského múzejníctva. In: Muzeológia a kultúrne dedičstvo, year: 2019, vol.: 7, number: 1, pages: 27-39. ISSN: 1339-2204.

Lending to Europe. 2015. Rotterdam: Netherlands Ministry of Education, Culture and Science. Available at: https://www.muziejai.lt/ImagesNew/LENDINGTOEUROPE_PDF_051105.pdf.

MENSCH, Peter van, MEIJER-VAN MENSCH, Leontine. 2015. New Trends in Museology II. Celje: Muzej novejšie zgodovine. ISBN: 978-961-6339-39-1.

NEMCOVÁ, Magda. 2011. Art in Motion. In: Ateliér, 9. Available at: http://www.mc-galerie.cz PAWLOWSKA, Aneta. 2020. African Art: The Journey from Ethnological Collection to the Museum of Art. In: Muzeológia a kultúrne dedičstvo, year: 2020, vol.: 8, number: 4, pages: 161 176. ISSN 1339-2204.

Postup pri dočasnom vývoze zbierkových predmetov z. múzei Slovenského národnébo múzea. 2014. Bratislava: Muzeologický kabinet SNM: Accessed October 10, 2019 at: http:/ /www.snm.sk/swift_data/ source/odborna_verejnost/dokumentacia/Postup_docas_vyvoz_ZP_SNM_130502014. doc.

Presentation report. Návrh na vyslovenie súhlasu Národnej rady Slovenskej republiky s Dohovorom Organizácie Spojených národov o jurisdikčných imunitách štátov a ich majetku sa predkladá v súlade s bodom C.1 uznesenia vlády Slovenskej republiky č. 297/2015 z 3. júna 2015. [on-line] Available at: https://www.nrsr.sk/web/Dynamic/DocumentPreview.aspx?DocID $=417153$.

Promotion of Museum Collection' Mobility and Loan Standards. 2015. Accessed October 10, 2019] at: https://uk.icom.museum/wp- content/uploads/2015/03/Encouraging_Collections_Mobility_A4.pdf.

Toolkit on Practical ways to reduce the cost of lending and borrowing of cultural objects among Member States of the European union. 2012. Open Method of Coordination (OMC) Working Group of EU Member States' Experts on the Mobility of Collections. European agenda for culture work plan for culture 2011-2014 [on-line]. Accessed October 17, 2019 at: http:/ / kultur.creative-europedesk.de/fileadmin/user_upload/omc_toolkit-mobility-ofcollections_en.pdf.

Toolkit. 2019. Slovak mutation of the Toolkit method is available in translation on the website of the Ministry of Culture of the Slovak Republic. Accessed October 15, 2019 at: http:// www.culture.gov.sk/extdoc/5846/3_ubor_nastrojov.

United Nation Convention on the Jurisdictional Immunities of States and Their Property. December 2, 2004, New York; Document OSN A/RES/59/38. Available at: https://undocs.org/en/A/ RES/59/38. 
United Nation Convention on the Jurisdictional Immunities of States and Their Property. Available at: https://www.nrsr.sk/web/Dynamic/DocumentPreview.aspx?DocID=417154

WEIL, Astrid. Mobilita sbírek - Časový přehled. In: Podporujeme mobilitu sbirek: cesta upred pro evropská muzea [online]. Fínska národná galéria 2010. Český preklad- Praha: Metodické centrum pro muzea výtvarného umění v národní galerii v Praze, 2014 [Accessed December 18, 2019 at: http://www.mcgalerie.cz/admin/files/pdf/ENCOURAGING-SBORNIK-konecna-verze.pdf. ISBN: 978-80-7035-555-8.

WOUDENBERG, Nout van. 2010. Immunity from seizure: a legal exploration. In: Encouraging collections mobility - A Way Forward for Museums in Europe. Accessed October 10, 2019 at: http://www.lendingforeurope.eu/fileadmin/CM/public/handbook/Encouraging_Collections_Mobility_A4.pdf.

Zákon č. 160/2018 Z. z. o podmienkach vývozu a dovozu predmetu kultúrnej hodnoty a o doplnení zákona č. 652/2004 Z. z. o orgánoch štátnej správy v colníctve a o zmene a doplnení niektorých zákonov v znení neskorších predpisov v znení zákona č. 38/2014 Z. z. a ktorým sa menia a dopĺñajú niektoré zákony.

Zákon č. 207/2009 z 28. apríla 2009 o podmienkach vývozu a dovozu predmetu kultúrnej hodnoty a o doplnení zákona č. 652/2004 Z. z. o orgánoch štátnej správy v colníctve a o zmene a doplnení niektorých zákonov v znení neskorších predpisov.

Zmena zákona o vývoze a dovoze predmetu kultúrnej hodnoty. Zákon č. 160/2018 Z. z., Available on-line on: https://www.noveaspi.sk/products/lawText/1/90299/1/2.

\section{Websites}

Methodological Centre for Visual Arts Museums in the National Gallery in Prague: http:// www.mc-galerie.cz.

Workshop on "The work of a specialist registrar in museums": http://www.mc-galerie.cz/ seminare-metodickehocentra/prace-registratora-specialisty-v-muzeich---workshop.html.

Forms for export: http://www.mc-galerie.cz/mobilita-sbirek-1/jak-administrovat-muzejni-vystavu---interaktivni-formulare.html.

Ministry of Culture of the Slovak Republic, export of cultural heritage: http://www.culture. gov.sk/posobnostministerstva/kulturne-dedicstvo-/vyvoz-predmetu-kulturnej-hodnoty-2ed.html. 